\section{Superior Colliculus}

John Brown ${ }^{1}$ and Gary Tye ${ }^{2}$

${ }^{1}$ Medical College of Georgia, Augusta, GA, USA

${ }^{2}$ Neurosurgery, Virginia Commonwealth

University, Richmond, VA, USA

\section{Cross-References}

- Basal Ganglia

- Inferior Colliculi

$\checkmark$ Pons

- Reticular Activating System

\section{References and Readings}

Oster, S. F., \& Sretavan, D. W. (2003). Connecting the eye to the brain: The molecular basis of ganglion cell axon guidance. British Journal of Ophthalmology, 87(5), 639-645.

Sten, B. E. (2005). The development of a dialogue between cortex and midbrain to integrate multisensory information. Experimental Brain Research, 166, 305-315. 